•编者按・

\title{
中国极小种群野生植物保护研究进展
}

\author{
臓润国1,2* \\ 1 (中国林业科学研究院森林生态环境与保护研究所, 国家林业和草原局森林生态环境重点实验室, 北京 100091) \\ 2 (南京林业大学南方现代林业协同创新中心, 南京 210037)
}

\section{Research progress in Wild Plant with Extremely Small Populations in China}

\author{
Runguo Zang ${ }^{1,2 *}$ \\ 1 Research Institute of Forest Ecology, Environment and Protection, Key Laboratory of Forest Ecology and Environment \\ of National Forestry and Grassland Administration, Chinese Academy of Forestry, Beijing 100091 \\ 2 Co-Innovation Center for Sustainable Forestry in Southern China, Nanjing Forestry University, Nanjing 210037
}

中国高等植物中受威胁物种共3,879种, 占评 估物种总数的 $10.84 \%$ (覃海宁等, 2017)。由于可利 用的资源有限, 不可能同时保护所有的物种, 只能 针对亟需保护的物种优先开展保护行动。为便于保 护和管理, 原国家林业局正式提出了极小种群野生 植物(Wild Plant with Extremely Small Populations, WPESP; 也有学者翻译为Plant Species with Extremely Small Populations, PSESP)的概念, 特指分布 地域狭窄, 长期受到外界因素干扰胁迫而呈现出种 群退化和个体数量持续减少, 以致种群和个体数量 都极少, 已经低于稳定存活界限的最小可存活种群, 而随时面临灭绝风险的野生植物(歲润国等, 2016)。 极小种群野生植物大多数为我国特有植物, 具有重 要的经济和科学价值, 如可用于作物改良、药用、 观赏或具有独特的生态进化意义(Ma et al, 2013)。 关于极小种群植物的保育, 必须强调针对的是野生 植物, 否则在保育实践中可能会引起误解, 特别是 基层单位和非专业人士更容易产生困惑, 对于人工 繁育或栽培种群数量比较大的物种如水杉(Metasequoia glyptostroboides)、东北红豆杉(Taxus cuspidata) 等更是如此, 因此, 本专辑中的极小种群野生植物 统一使用WPESP的译法。

《全国极小种群野生植物拯救保护工程规划 (2011-2015)》确定了首批120种重点保护的极小种
群野生植物, 包含36种国家I级重点保护植物, 26种 国家II级重点保护植物, 58种省级重点保护植物。包 含的植物主要有以下几类: 一是野外种群数量极 少、极度濒危、随时有灭绝危险的野生植物; 二是 生境要求独特、生态幅狭窄的野生植物; 三是潜在 基因价值不清楚，其灭绝将引起基因流失、生物多 样性降低、社会经济价值损失巨大的种群相对较小 的野生植物。

作为最易丧失的生物资源之一，如果保护不及 时, WPESP的生物和基因价值很可能在人类了解之 前就伴随着物种的灭绝而消失, 最终给生态系统和 人类社会带来不可估量的损失(张则瑾等, 2018)。因 此, 致力于 WPESP保护研究在我国当前的生物多 样性保护研究中尤为迫切。WPESP的概念自提出后 在中国各级政府部门和公众中的认知度越来越高, 目前国家和地区层面上也实施了多项WPESP保护 战略和行动。该概念的提出及其拯救保护工程的实 施在我国野生植物保护中具有里程碑式的意义。

第一，确定了野生植物保护的重点目标。保护 优先种的确定是野生植物保护的难点之一(Xu et al, 2019)。我国需要保护的野生植物种类众多, 此前保 护管理部门只能针对所有的重点保护植物和珍稀 濒危植物进行宏观的保护管理和规划, 难以针对特 定的物种开展深入具体的保护行动(杨文忠等, 
2015)。WPESP保护工程不仅明确了需要优先开展 保护的 120 个物种, 还根据保护对象提出了保护小 区建设、种质资源保存、近地保护和野外回归等相 关保护措施(许再富和郭辉军, 2014)。

第二，革新了野生植物保护的理念和方法。 WPESP提出了以种群为基本保护单元的理念和方 法, 强调保护的实质是对野生植物种群数量、结构 和动态等的调节与管理(杨文忠等, 2015)。这一概念 也促进了种群生态学、生殖生物学、生物遗传学和 保护生物学等相关学科的发展(Ren et al, 2012), 多 学科相互交叉和渗透的综合性研究也能促进基础 理论和应用技术研究更好地服务于我国野生植物 保护实践(藏润国等, 2016)。

第三, 改变了野生植物保护策略。以前我国的 野生植物保护以法律法规、行政手段和宣传教育等 为主要策略, 而WPESP的概念强调了植物种群生 态学原理和方法在保护实践中的应用(周云等, 2012), 并发展了很多适用于WPESP的保护策略和 技术, 如WPESP天然种群的就地保护、近地保护、 保护小区, WPESP种群恢复和重建等(Ren et al, 2014; 杨文忠等, 2016)。

总体而言, 关于WPESP的保护理念推动了中 国的生物多样性保护行动, 并进一步明确了野生植 物保护的方向和目标。

自保护工程实施以来, 全国已有23个省基于野 外调查、实验分析和保护实践开展了WPESP拯救保 护研究(Sun et al, 2019)。张则瑾等(2018)基于120种 WPESP的高精度分布数据和自然保护区分布数据, 首次分析了我国极小种群野生植物的分布格局及 其保护现状。研究者还通过统计不同省份和地区 WPESP的种类、数量、分布和拯救保护的现状, 揭 示了保护中存在的问题(郑进烜等, 2013; 贺水莲等, 2016; 孙湘来等, 2017)。针对我国WPESP目前面临 的生存状况, 开展物种生态学、群落结构、生境调 查和监测, 观测其种群动态过程, 为探索其濒危机 制, 开展就地保护、生境修复和迁地保护等保护方 案提供了理论依据(王世泮等, 2018; 张宇阳等, 2018)。一些研究在对目标物种及其近缘种的生态学 特征、生物学特性、遗传多样性水平和遗传结构研 究的基础上，提出了WPESP种苗繁育和回归引种、 种质资源保存(种子园、繁育圃)、保护小区建设等 具体的技术方法(金芯等, 2014; 杨文忠等, 2016; 曾
洪和陈小红, 2017)。还有一些研究在对目标物种迁 地保护、近地保护和回归自然的“人工种群”进行了 长期管护和监测的基础上，对保护的有效性做出了 科学评价(李西贝阳等, 2017; 康洪梅等, 2018)。尽 管目前已经取得了上述研究进展，但是有关 WPESP的濒危原因及相应解濒技术的研究还非常 缺乏, 不足以为拯救保护工程有效实施提供科学指 导。因此, 从WPESP的种群衰退与更新限制机理、 种群扩繁与复壮技术等方面开展研发, 将为 WPESP的保护和恢复提供系统的科技支撑。

2016年启动的国家重点研发计划项目 “典型极 小种群野生植物保护与恢复技术研究 (2016YFC0503100)”，以14种典型极小种群野生植 物为对象, 开展了种群生存力分析、种质资源保存、 就地保护与生境恢复、扩繁、迁地保护和野外回归 6 个方面的研究。该项目实施以来, 通过大量的野外 调查、实验分析和实践示范，初步取得了以下成果： (1)基于种群统计学特征及生境变化特征, 建立了适 用于WPESP的种群生存力分析模型，并用于量化 界定极小种群野生植物; (2)采用基因组学方法确定 了水杉核心种质资源，揭示了东北红豆杉、坡垒 (Hopea hainanensis)和天目铁木(Ostrya rehderiana) 的致濒机理; (3)突破了所有 14 个物种的人工扩繁限 制瓶颈，形成了一系列扩繁技术，建立了 5 个繁育 基地, 培育了一定数量的人工繁殖植株, 为种群的 复壮和野外回归提供了可能的苗源; (4)通过实验分 析和实践摸索，形成了一系列的保护技术，建立了 14 个就地保护示范区, 并重点在全国不同气候区建 立了8处迁地保护示范区，将WPESP分散到在典型 地段建立的具有一定规模的保护和回归基地进行 保存，降低了物种的灭绝风险。

本专辑汇集了14篇文章，从多个方面介绍中国 WPESP的最新研究进展, 主要基于目前野外调查 获取的种群结构、群落调查和功能性状数据, 针对 极小种群野生植物种群及群落动态、遗传多样性及 核心种质资源、生境适应策略等方面展开分析。另 外，基于文献综述了极小种群野生植物生存力分析 的潜在方法、分子遗传标记在濒危物种保护中的应 用、濒危裸子植物的致濒因素及14种中国典型极小 种群野生植物的繁殖特性和人工繁殖方法。其他相 关结果已经陆续在国内外期刊发表或正在撰写中。 本专辑的内容主要包括以下方面: 
(1)生存潜力。种群生存力分析(population viability analysis, PVA) 是评估种群所受威胁、灭绝或衰 退风险以及恢复可能性的有效方法。然而, 极小种 群野生植物的个体数据难以获取, 种群参数估计困 难, 这导致传统PVA方法在此类种群中的应用存在 局限性(林勇等, 2017)。陈冬东等(2020)提出了采用 小样本非统计方法(灰色系统模型、贝叶斯方法、自 助法)分析极小种群野生植物生存力并量化不同因 素对其生存力的影响程度, 对极小种群野生植物的 保护措施提供理论指导。种群的径级结构、年龄结 构、性比等特征对分析种群生存潜力以及种群对全 球和区域的环境变化、人类干扰的响应等方面均具 有重要意义(许恒和刘艳红，2018a，b)。宋圭涁等 (2020)发现西藏吉隆地区6个天然密叶红豆杉(Taxus fuana)种群的大小、性比、雌雄个体的大小级结构 以及空间分布格局等均表现出不同, 这一结果为结 合各种群本身的发展动态、受干扰类型以及区域环 境因子差异进行极小种群野生植物原生种群的针 对性保护提供了理论基础。

(2)濒危机制和受威胁因子。极小种群野生植物 因其分布地域狭窄、种群衰退严重, 个体数量低于 其稳定存活界限, 随时濒临灭绝, 砍伐等人类干扰 进一步导致极小种群野生植物种群个体数量减少, 群落结构改变, 加剧了物种的灭绝风险(Fan et al, 2020)。但是目前有关极小种群野生植物种群濒危机 制的研究较少。李帅锋等(2020)通过分析云南省太 阳河自然保护区藤菄(Eleutharrhena macrocarpa)生 境内乔木层与灌木层中木本植物的种间关联性以 及群落的稳定性，揭示了种间关联性在藤束濒危机 制中的作用, 以及生境地群落的严格保护对藤㫫种 群更新的重要性。赵志霞等(2020)分析了崖柏(Thuja sutchuenensis)重度砍伐后其种群的径级结构、种群 生存力、所在群落结构动态等特征, 发现砍伐严重 影响了崖柏种群生存力及其在群落中的优势度。

(3)种质资源保护。遗传多样性是生物多样性的 重要组成部分, 描绘极小种群野生植物的遗传组成 分布、揭示其响应环境变化时的遗传机制对理解其 致濒机理进而采取相应的保护措施极为重要 (Aboukhalid et al, 2017)。李媛媛等(2020)探讨了在 濒危物种保护的几个环节一一识别保护单元、制定 保护计划、指导实施过程、评估保护成效中分子遗 传标记的作用和意义, 对分子标记应用于保护实践
的发展方向进行了展望。苏金源等(2020)探讨了濒 危裸子植物应对环境恶化的维持机制、致濒因素和 保护方案, 强调了通过遗传多样性研究来充分认识 极小种群致濒机理对于指导其保护和种群恢复的 重要性。陈俊等(2020)分析了湖北星斗山国家级自 然保护区水杉原生母树种群功能性状对树木形态、 地形因子及人为干扰的响应机制，表明人为干扰对 母树生长影响较大, 因此建议实行人工辅助更新, 并适度减少农业和建筑对现存母树的影响。

(4)就地保护及生境恢复。就地保护在植物保育 中起着至关重要的作用, 因为它对破坏或改变物种 栖息地的行为起到了禁止作用。由于极小种群野生 植物一般生境要求独特、生态幅狭窄，因此保护其 原生种群和维护其自然生境是保护的重要方式之 一(Volis, 2016)。刘丹等(2020)对东北红豆杉植物群 落的物种组成、群落结构和类型、物种多样性进行 了调查和数量分类，定性地说明了植被类型与环境 的关系以及群落生境的基本特征。王世形等(2020) 分析了黄梅秤锤树野生种群的叶片功能性状和叶 片生态化学计量特征对湖岸带微生境变化的响应 及其适应策略。路兴慧等(2020)分析了生物与非生 物生境特征对野生坡垒种群更新幼苗多度的影响, 揭示了坡垒种群从幼苗至幼树阶段存在的增补限 制和关键限制因子。

(5)生殖生物学。繁殖是植物生活史中最为关键 的环节之一, 也是种群更新与维持的重要环节。极 小种群野生植物自身生殖繁育力的衰退、生活力的 下降等是导致其走向濒临灭绝的内在原因(Volis, 2016; Wade et al, 2016)。邓莎等 (2020)对项目选择的 14种中国典型极小种群野生植物的繁殖特性和人 工繁殖方法进行了综述, 介绍了这些物种在种苗繁 殖研究方面取得的进展。冯秋红等(2020)以天然分 布的5个梓叶槭(Acer catalpifolium)小种群为研究对 象, 探讨了其 11 个种实性状在种群内和种群间存在 的表型变异, 结果表明在取种时应该采集不同种源 地的种子, 以最大程度上保存物种的表型多样性, 确定优质种质资源候选地。吴漫玲等(2020)以根据 等位基因差异篮选出的 40 株原生水杉核心种质资 源为对象，分析了其产种、发芽、幼苗生长与存活阶 段的生活史规律, 验证了不同母树个体性状是影响 水杉种子性状、幼苗生长及自然更新的重要因素。

(6)回归研究。野外回归是扩大极小种群野生植 
物种群的有效途径, 目前急需探索极小种群野生植 物野外回归的基础理论和关键技术，以制定相应的 保护对策。研究植物的生理生态特征对不同野外回 归生境的适应性, 是科学评价极小种群野生植物种 群回归生境适宜性的关键指标(吕程瑜和刘艳红, 2018)。张宇阳等(2020)探讨了4种不同光照条件对 野外回归梓叶槭幼树的形态特征、光合特征、类黄 酮指数及叶绿素含量等的影响, 为该物种的野外回 归提供了理论和实践基础, 并为其他极小种群野生 植物回归生境适宜性的探索研究提供了借鉴。

中国在极小种群野生植物保护方面虽然已经 取得了一些研究进展, 但我们必须认识到, 极小种 群野生植物由于其种群数量小、面临胁迫大及繁殖 困难等固有特点, 以往的保护理论和方法并不完全 适用。因此, 希望看到更多的工作基于更广泛的学 科领域, 在极小种群野生植物发育生物学、繁殖生 态学、种群遗传学、种群生态学和群落生态学等各 个方面开展有针对性的长期观察、理论和实验研究, 以及更多的以应用为导向的实践研究。

\section{参考文献:}

Aboukhalid $\mathrm{K}$, Machon $\mathrm{N}$, Lambourdière $\mathrm{J}$, Abdelkrim J, Bakha M, Douaik A, Korbecka-Glinka G, Gaboun F, Tomi F, Lamiri A, Al Faiz C (2017) Analysis of genetic diversity and population structure of the endangered Origanum compactum, from Morocco, using SSR markers: Implication for conservation. Biological Conservation, 212, 172-182.

Chen DD, Li ZQ (2020) Population viability analysis of Wild Plant with Extremely Small Populations (WPESP): Methods, problems and prospects. Biodiversity Science, 28, 358-366. (in Chinese with English abstract) [陈冬东, 李镇清 (2020) 极小种群野生植物生存力分析: 方法、问题与展望. 生物 多样性, 28, 358-366.]

Chen J, Yao L, Ai XR, Zhu J, Wu ML, Huang X, Chen SY, Wang J, Zhu Q (2020) Adaptive strategies of functional traits of Metasequoia glyptostroboides parent trees to changing habitats. Biodiversity Science, 28, 296-302. (in Chinese with English abstract) [陈俊, 姚兰, 艾训儒, 朱江, 吴漫玲, 黄小, 陈思艺, 王进, 朱强 (2020) 基于功能性 状的水杉原生母树种群生境适应策略. 生物多样性, 28, 296-302.]

Deng S, Wu YN, Wu KL, Fang L, Li L, Zeng SJ (2020) Research progress of artificial propagation of 14 species of Wild Plant with Extremely Small Populations in China. Biodiversity Science, 28, 385-400. (in Chinese with English abstract) [邓莎, 吴艳妮, 吴坤林, 房林, 李琳, 曾宋君 (2020) 14种中国典型极小种群野生植物人工繁殖研究进
展. 生物多样性, 28, 385-400.]

Fan KX, Ai XR, Yao L, Huang JH, Xu Y, Lu XH, Ding Y, Zang RG (2020) Do climate and human disturbance determine the sizes of endangered Metasequoia glyptostroboides trees in their native range? Global Ecology and Conservation, 21, doi.org/10.1016/j.gecco.2019.e00850.

Feng QH, Li DF, Yu T, Li JQ, Ma WB, Zhang L (2020) Phenotypic fruit and seed variations of Acer catalpifolium, a Wild Plant with Extremely Small Populations in China. Biodiversity Science, 28, 314-322. (in Chinese with English abstract) [冯秋红, 李登峰, 于涛, 李俊清, 马文宝, 张雷 (2020) 极小种群野生植物梓叶槭种实表型变异特征. 生 物多样性, 28, 314-322.]

He SL, Yang Y, Du J, Meng J, Wu HZ (2016) Status of rescue and conservation on minimum population of wild plants in Yunnan Province-Based on genetic diversity analysis. Journal of Anhui Agricultural Sciences, 44, 31-34, 38. (in Chinese with English abstract) [贺水莲，杨扬，杜娟，孟静， 吴红芝 (2016) 云南省极小种群野生植物保护研究现状 一一基于遗传多样性分析. 安徽农业科学, 44, 31-34, 38.]

Jin R, Shi YX, Xu T, Yang MZ, Sima YK (2014) Study on genetic diversity of endangered and endemic plant of Magnolia odoratissima (Magnoliaceae) in Yunnan Province. Journal of West China Forestry Science, 43, 80-84. (in Chinese with English abstract) [金芯，石雨金金，徐涛，杨明 挚, 司马永康 (2014) 云南特有濒危植物馨香木兰的遗 传多样性研究. 西部林业科学, 43, 80-84.]

Kang HM, Zhang SS, Shi FQ, Yang WZ (2018) Effects of major climate factors on growth of Nyssa yunnanensis, a plant species with extremely small populations. Journal of Northeast Forestry University, 46(7), 23-27. (in Chinese with English abstract) [康洪梅, 张珊珊, 史富强, 杨文忠 (2018) 主要气候因子对极小种群野生植物云南蓝果树生 长的影响. 东北林业大学学报, 46(7), 23-27.]

Li SF, Lang XD, Huang XB, Liu WD, Su JR, Xu CH, Li ZH, $\mathrm{Xu} F D$ (2020) Interspecific association of woody plant species and community stability in the Eleutharrhena macrocarpa habitat. Biodiversity Science, 28, 350-357. (in Chinese with English abstract) [李帅锋, 郎学东, 黄小波, 刘万德, 苏建荣, 徐崇华, 李智宏, 徐凡迪 (2020) 藤束 生境地木本植物种间关联性与群落稳定性. 生物多样性, 28, 350-357.]

Li XBY, Fu L, Wang FG, Xing FW (2017) Michelia guangdongensis (Magnoliaceae), an endangered plant species with extremely small populations, should be evaluated as CR C2a(i); D. Biodiversity Science, 25, 91-93. (in Chinese) [李 西贝阳, 付琳, 王发国, 邢福武 (2017) 极小种群植物广 东含笑应当被评估为极危等级. 生物多样性, 25, 91-93.]

Li YY, Liu CN, Wang R, Luo SX, Nong SQ, Wang JW, Chen XY (2020) Applications of molecular markers in conserving endangered species. Biodiversity Science, 28, 367-375. (in Chinese with English abstract) [李媛媛, 刘超男, 王嵘, 罗 水兴, 农寿千, 王静雯, 陈小勇 (2020) 分子标记在濒危 
物种保护中的作用. 生物多样性, 28, 367-375.]

Lin Y, Ai XR, Yao L, Guo QJ, Zhang MX, Chen J (2017) Population structure and dynamics of Metasequoia glytostroboides parent trees. Chinese Journal of Ecology, 36, 1531-1538. (in Chinese with English abstract) [林勇, 艾训 儒, 姚兰, 郭秋菊, 张敏霞, 陈俊 (2017) 水杉原生母树 种群结构与动态. 生态学杂志, 36, 1531-1538.]

Liu D, Guo ZL, Cui XY, Fan CN (2020) Comparison of five associations of Taxus cuspidata and their species diversity. Biodiversity Science, 28, 340-349. (in Chinese with English abstract) [刘丹, 郭忠玲, 崔晓阳, 范春楠 (2020) 5种东北 红豆杉植物群丛及其物种多样性的比较. 生物多样性, 28, 340-349.]

Lu XH, Zang RG, Ding Y, Huang JH, Xu Y (2020) Habitat characteristics and its effects on seedling abundance of Hopea hainanensis, a Wild Plant with Extremely Small Populations. Biodiversity Science, 28, 289-295. (in Chinese with English abstract) [路兴慧, 喊润国, 丁易, 黄继红, 许 玥 (2020) 极小种群野生植物坡垒的生境特征及其对幼 苗多度的影响. 生物多样性, 28, 289-295.]

Lü CY, Liu YH (2018) Provenance difference in growth traits and photosynthetic characteristics of Acer catalpifolium seedlings under different shading conditions. Chinese Journal of Applied Ecology, 29, 2307-2314. (in Chinese with English abstract) [吕程瑜, 刘艳红 (2018) 不同遮荫条件 下梓叶槭幼苗生长与光合特征的种源差异. 应用生态学 报, 29, 2307-2314.]

Ma YP, Chen G, Grumbine RE, Dao ZL, Sun WB, Guo HJ (2013) Conserving plant species with extremely small populations (PSESP) in China. Biodiversity and Conservation, 22, 803-809.

Qin HN, Yang Y, Dong SY, He Q, Jia Y, Zhao LN, Yu SX, Liu HY, Liu B, Yan YH, Xiang JY, Xia NH, Peng H, Li ZY, Zhang ZX, He XJ, Yin LK, Lin YL, Liu QR, Hou YT, Liu Y, Liu QX, Cao W, Li JQ, Chen SL, Jin XH, Gao TG, Chen WL, Ma HY, Geng YY, Jin XF, Chang CY, Jiang H, Cai L, Zang CX, Wu JY, Ye JF, Lai YJ, Liu B, Lin QW, Xue NX (2017) Threatened Species List of China's Higher Plants. Biodiversity Science, 25, 696-744. (in Chinese and in English) [覃海宁, 杨永, 董仕勇, 何强, 贾渝, 赵莉娜, 于胜祥, 刘慧圆, 刘博, 严岳鸿, 向建英, 夏念和, 彭华, 李振宇, 张志翔, 何兴金, 尹林克, 林余霖, 刘全儒, 侯 元同, 刘演, 刘启新, 曹伟, 李建强, 陈世龙, 金效华, 高 天刚, 陈文俐, 马海英, 耿玉英, 金孝锋, 常朝阳, 蒋宏, 蔡蕾, 蔵春金銈, 武建勇, 叶建飞, 赖阳均, 刘冰, 林秦文, 薛纳新 (2017) 中国高等植物受威胁物种名录. 生物多 样性, 25, 696-744.]

Ren H, Jian SG, Liu HX, Zhang QM, Lu HF (2014) Advances in the reintroduction of rare and endangered wild plant species. Science China: Life Sciences, 57, 603-609.

Ren H, Zhang QM, Lu HF, Liu HX, Guo QF, Wang J, Jian SG, Bao HO (2012) Wild plant species with extremely small populations require conservation and reintroduction in
China. Ambio, 41, 913-917.

Song YB, Xu L, Duan JP, Zhang WJ, Shentu XL, Li TX, Zang RG, Dong M (2020) Sex ratio and spatial pattern of Taxus fuana, a Wild Plant with Extremely Small Populations in Tibet. Biodiversity Science, 28, 269-276. (in Chinese with English abstract) [宋圭彬, 徐力, 段俊鹏, 张卫军, 申屠晓 露, 李天翔, 藏润国, 董鸣 (2020) 西藏极小种群野生植 物密叶红豆杉种群的性比及雌雄空间格局. 生物多样性, 28, 269-276.]

Su JY, Yan Y, Li C, Li D, Du F (2020) Informing conservation strategies with genetic diversity in Wild Plant with Extremely Small Populations: A review on gymnosperms. Biodiversity Science, 28, 376-384. (in Chinese with English abstract) [苏金源, 燕语, 李冲, 李丹, 杜芳 (2020) 通过 遗传多样性探讨极小种群野生植物的致濒机理及保护策 略: 以裸子植物为例. 生物多样性, 28, 376-384.]

Sun WB, Ma YP, Blackmore S (2019) How a new conservation action concept has accelerated plant conservation in China? Trends in Plant Science, 24, 4-6.

Sun XL, Shi SZ, Zhao XY, Xu YY, Hong XJ (2017) Present situation and protection countermeasures of wild and endangered plants in minimal population in Hainan Province. Journal of Green Science and Technology, (18), 11-13. (in Chinese with English abstract) [孙湘来, 石绍章, 赵小迎, 许洋瑜, 洪小江 (2017) 海南省极小种群野生濒危植物 现状与保护对策. 绿色科技, (18), 11-13.]

Volis S (2016) How to conserve threatened Chinese plant species with extremely small populations? Plant Diversity, 38, 45-52.

Wade EM, Nadarajan J, Yang XY, Ballesteros D, Sun WB, Pritchard HW (2016) Plant species with extremely small populations (PSESP) in China: A seed and spore biology perspective. Plant Diversity, 38, 209-220.

Wang ST, Wu H, Liu MT, Zhang JX, Liu JM, Meng HJ, Xu YZ, Qiao XJ, Wei XZ, Lu ZJ, Jiang MX (2018) Community structure and dynamics of a remnant forest dominated by a plant species with extremely small population (Sinojackia huangmeiensis) in central China. Biodiversity Science, 26, 749-759. (in Chinese with English abstract) [王世羏, 吴浩, 刘梦婷, 张佳金金, 刘检明, 孟红杰, 徐耀粘, 乔秀娟, 魏 新增, 卢志军, 江明喜 (2018) 极小种群野生植物黄梅秤 锤树群落结构与动态. 生物多样性, 26, 749-759.]

Wang ST, Xu YZ, Yang T, Wei XZ, Jiang MX (2020) Impacts of microhabitats on leaf functional traits of the wild population of Sinojackia huangmeiensis. Biodiversity Science, 28, 277-288. (in Chinese with English abstract) [王世坓, 徐耀粘, 杨腾, 魏新增, 江明喜 (2020) 微生境对黄梅秤 锤树野生种群叶片功能性状的影响. 生物多样性, 28, 277-288.]

Wu ML, Yao L, Ai XR, Zhu J, Zhu Q, Wang J, Huang X, Hong JF (2020) The reproductive characteristics of core germplasm in a native Metasequoia glyptostroboides population. Biodiversity Science, 28, 303-313. (in Chinese with English 
abstract) [吴漫玲, 姚兰, 艾训儒, 朱江, 朱强, 王进, 黄 小, 洪建峰 (2020) 水杉原生种群核心种质资源的繁殖 特性. 生物多样性, 28, 303-313.]

Xu H, Liu YH (2018a) The population structure, dynamics features and protection strategy of Acer catalpifolium extremely small population. Journal of Nanjing Forestry University (Natural Sciences Edition), 43, 47-54. (in Chinese with English abstract) [许恒, 刘艳红 (2018a) 极小种群梓叶槭 种群结构及动态特征. 南京林业大学学报(自然科学版), 43, 47-54.]

Xu H, Liu YH (2018b) Relationship between diameter class structure and intraspecific and interspecific competitions of precious and endangering plant Acer catalpifolium. Acta Botanica Boreali-Occidentalia Sinica, 38, 1160-1170. (in Chinese with English abstract) [许恒, 刘艳红 (2018b) 珍 稀濒危植物梓叶槭种群径级结构与种内种间竞争关系. 西北植物学报, 38, 1160-1170.]

Xu Y, Huang JH, Lu XH, Ding Y, Zang RG (2019) Priorities and conservation gaps across three biodiversity dimensions of rare and endangered plant species in China. Biological Conservation, 229, 30-37.

Xu ZF, Guo HJ (2014) Near situ conservation for wild plant species with extremely small populations. Plant Diversity and Resources, 36, 533-536. (in Chinese with English abstract) [许再富, 郭辉军 (2014) 极小种群野生植物的 近地保护. 植物分类与资源学报, 36, 533-536.]

Yang WZ, Li YJ, Zhang SS, Yu CY, Kang HM, Shi FQ, Chen Y, Zhang KF (2016) Mini-reserve of Nyssa yunnanensis: The first practice of mini-reserve construction for plant species with extremely small populations (PSESP) in China. Journal of West China Forestry Science, 45, 149-154. (in Chinese with English abstract) [杨文忠, 李永杰, 张珊珊, 余昌元, 康洪梅, 史富强, 陈勇, 张快富 (2016) 云南蓝 果树保护小区一一国首个极小种群野生植物保护小区 建设实践. 西部林业科学, 45, 149-154.]

Yang WZ, Xiang ZY, Zhang SS, Kang HM, Shi FQ (2015) Plant species with extremely small populations (PSESP) and their significance in China's national plant conservation strategy. Biodiversity Science, 23, 419-425. (in Chinese with English abstract) [杨文忠, 向振勇, 张珊珊, 康洪梅, 史富强 (2015) 极小种群野生植物的概念及其对我国野 生植物保护的影响. 生物多样性, 23, 419-425.]

Zang RG, Dong M, Li JQ, Chen XY, Zeng SJ, Jiang MX, Li ZQ, Huang JH (2016) Conservation and restoration for typical critically endangered wild plants with extremely small population. Acta Ecologica Sinica, 36, 7130-7135. (in Chinese with English abstract) [喊润国, 董鸣, 李俊清, 陈 小勇, 曾宋君, 江明喜, 李镇清, 黄继红 (2016) 典型极 小种群野生植物保护与恢复技术研究. 生态学报, 36,
7130-7135.]

Zeng H, Chen XH (2016) Ecological niche of extremely small population of wild Oyama sinensis. Journal of Sichuan Agricultural University, 35, 220-226. (in Chinese with English abstract) [曾洪, 陈小红 (2016) 极小种群野生植 物圆叶玉兰的生态位研究. 四川农业大学学报, 35, 220-226.]

Zhang YY, Ma WB, Yu T, Ji HJ, Gao J, Li JQ, Gao S, Ke L (2018) Population structure and community characteristics of Acer catalpifolium Rehd. Chinese Journal of Applied and Environmental Biology, 24, 697-703. (in Chinese with English abstract) [张宇阳, 马文宝, 于涛, 姬慧娟, 高健, 李俊清, 高尚, 柯蕾 (2018) 梓叶槭的种群结构和群落特 征. 应用与环境生物学报, 24, 697-703.]

Zhang YY, Yu T, Ma WB, Wang F, Tian C, Li JQ (2020) Physiological and morphological effects of different canopy density on reintroducing Acer catalpifolium to wild. Biodiversity Science, 28, 323-332. (in Chinese with English abstract) [张宇阳, 于涛, 马文宝, 王飞, 田成, 李俊清 (2020) 不同郁闭度对野外回归梓叶槭幼树形态和生理特 征的影响. 生物多样性, 28, 323-332.]

Zhang ZJ, Guo YP, He JS, Tang ZY (2018) Conservation status of wild plant species with extremely small populations in China. Biodiversity Science, 26, 572-577. (in Chinese with English abstract) [张则瑾, 郭炎培, 贺金生, 唐志尧 (2018) 中国极小种群野生植物的保护现状评估. 生物多 样性, 26, 572-577.]

Zhao ZX, Zhao CM, Deng SY, Shen GZ, Xie ZQ, Li JQ, Xiong GM (2020) Community structure and dynamics of a remnant forest dominated by Thuja sutchuenensis after deforestation. Biodiversity Science, 28, 333-339. (in Chinese with English abstract) [赵志霞, 赵常明, 邓舒雨, 申国珍, 谢宗强, 熊 高明, 李俊清 (2020) 重度砍伐后极小种群野生植物崖 柏群落结构动态. 生物多样性, 28, 333-339.]

Zheng JX, Hua CL, Tao J, Yu CY, He JF, Zi SZ (2013) Status and strategies of rescue and conservation on minimum population of wild plants in Yunnan Province. Forest Inventory and Planning, 38(4), 61-66. (in Chinese with English abstract) [郑进烜, 华朝朗, 陶晶, 余昌元, 贺佳飞, 子世 泽 (2013) 云南省极小种群野生植物拯救保护现状与对 策研究. 林业调查规划, 38(4), 61-66.]

Zhou Y, Jiang H, Yang WZ, Zhang SS, Xiang ZY (2012) Study on stock of Pinus wangii, an extremely small population species. Journal of West China Forestry Science, 41(3), 84-87. (in Chinese with English abstract) [周云, 蒋宏, 杨 文忠, 张珊珊, 向振勇 (2012) 极小种群植物毛枝五针松 的野生资源状况研究. 西部林业科学, 41(3), 84-87.]

(责任编辑: 周玉荣) 